\title{
Tax Mimicking in Local Business Taxation: Quasi-experimental Evidence from Portugal
}

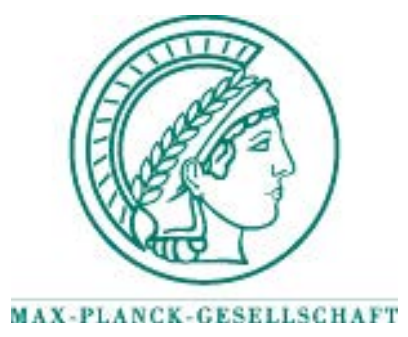

Max Planck Institute for

Tax Law and Public Finance

Department of Business and Tax Law

Department of Public Economics

http:/ / www.tax.mpg.de 
Working papers of the Max Planck Institute for Tax Law and Public Finance Research Paper Series serve to disseminate the research results of work in progress prior to publication to encourage the exchange of ideas and academic debate. Inclusion of a paper in the Research Paper Series does not constitute publication and should not limit publication in any other venue. The preprints published by the Max Planck Institute for Tax Law and Public Finance represent the views of the respective author(s) and not of the Institute as a whole. Copyright remains with the author(s).

Max Planck Institute for Tax Law and Public Finance

Marstallplatz 1

D-80539 Munich

Tel: $\quad+498924246-0$

Fax: $\quad+498924246-501$

E-mail: ssrn@tax.mpg.de

http://www.tax.mpg.de 


\title{
Tax Mimicking in Local Business Taxation: Quasi-experimental Evidence from Portugal
}

\author{
Mariana Lopes da Fonseca*
}

\begin{abstract}
I exploit an exogenous reform introducing a local business tax in Portugal to study tax mimicking among jurisdictions. The identification strategy relies on a quasi-experimental difference-in-differences methodology and heterogeneity in treatment intensity. Results provide evidence of significant short-run tax mimicking that decreases over time. I study possible generating processes underlying the strategic interaction among municipalities and find significant evidence of electoral concerns. These electoral concerns are not met with electoral consequences at the local elections, which may be behind the diffusion of local business taxation in the long run.
\end{abstract}

Keywords: tax mimicking, yardstick competition, local reform

JEL codes: D72, H71, H77

* Max Planck Institute for Tax Law and Public Finance, Department of Public Economics, Marstallplatz 1, 80539 Munich, Germany. E-mail: Mariana.Lopes-da-Fonseca@tax.mpg.de. 


\section{Introduction}

The theoretical literature on fiscal interdependencies among local governments models different interaction processes leading to a variety of outcomes concerning the level of taxation and the provision of public goods ${ }^{1}$ How the decision of one jurisdiction influences others depends, among other things, on specific assumptions on the nature of the central planner, whether tax rates are residual or choice variables, or the degree of factor mobility between jurisdictions. In this article, I aim to identify strategic interactions in tax setting and to explore the underlying mechanisms.

I exploit an exogenous reform of the local finances in Portugal in 2007 that substituted a conditional business surcharge by an unconditional local business tax. Inference rests on a quasi-experimental difference-in-differences (diff-in-diff) methodology and heterogeneity in treatment intensity. I proxy treatment intensity by the geographic location of municipalities and their exposure to jurisdictions relying on the surcharge in the pre-treatment period. The empirical analysis is divided into a two-step procedure. The first step deals with the identification of tax mimicking, while the second tests different generating processes to identify potential underlying mechanisms.

I find evidence of tax mimicking in the short run, that dissipates over time as more jurisdictions start to rely on local business taxation. In the second step of the analysis, I fail to provide evidence of tax competition, expenditure competition, spillover effects, or policy diffusion by social learning. I identify, however, electoral concerns in the tax setting behaviour. I also find that these concerns are not met with electoral consequences in the 2009 and 2013 local elections. A possible explanation for the results is the existence of short-term yardstick competition that, in the absence of retrospective voting, led to a diffusion in local business taxation. In this context, elections are a source of information for politicians to assess the impact of their policies.

\footnotetext{
${ }^{1}$ For a review of the theoretical literature see, e.g.Wilson and Wildasin 2004.
} 
Studying local fiscal interactions entails two main difficulties. First, the complexity of causally identifying the treatment effects. Recent literature has shown the need to rely on quasi-experimental methodologies that capture sources of exogenous variation for causal identification. Second, a multitude of processes that are not exclusive to intergovernmental interactions may generate spatial patterns in policy decisions (Manski, 2000). Moreover, the lack of significant evidence on inter-jurisdictional dependence in tax setting does not mean interactions do not exist. Instead, it is necessary to pinpoint the mechanisms at play within the different contexts for identification.

Large branches of the theoretical literature focus on the competition over tax bases and votes - see, e.g.the seminal contributions by Bradford and Oates (1971) on tax competition and Salmon (1987) on the competition over votes, referred to as yardstick competition (Shleifer, 1985) - as well as on the spillover effects of policy decisions (Case et al., 1993). Tax competition may lead to a race to the bottom (Wilson, 1986; Zodrow and Mieszkowski, 1986) or to the top (Baldwin and Krugman, 2004), yardstick competition predicts a correlation between tax setting and electoral outcomes (Besley and Case, 1995), and spillover effects can generate positive or negative interdependencies in tax rates across jurisdictions (Wildasin, 1988). Also, models of expenditure competition (Wilson and Gordon, 2003) and, more recently, social learning in tax setting (Becker and Davies, 2014) also feature in the theoretical literature, usually predicting strategic complementarity in the tax setting behaviour between jurisdictions.

Following the theoretical developments, a large body of empirical studies focuses on the identification of strategic interactions among local governments. For a long time, the default methodological approach to the study of fiscal interdependencies among jurisdictions was the Spatial Lag (SL) framework, often combined with instrumental variables based on the characteristics of neighbouring municipalities.2 Gibbons and Overman (2012), however,

\footnotetext{
${ }^{2}$ For a review of the spatial empirical literature see, e.g. Brueckner $(2003)$.
} 
argue that this methodology should have no causal interpretation. Indeed, three recent studies, by Lyytikainen (2012), Baskaran (2014), and Isen (2014) show that the SL regression framework consistently overestimates fiscal interactions among local governments. Moreover, all three studies fail to identify inter-governmental interactions within quasiexperimental settings, bringing into question the existing body of evidence on strategic tax setting.

Despite the crucial methodological contribution, these studies do not settle the debate on the existence or nature of strategic interactions among local governments. All three studies rely on jurisdictions that suffer treatment only indirectly and do not investigate whether countervailing effects steaming from different mechanisms lead to the insignificant results. In fact, two recent quasi-experimental studies identify strategic tax interaction along state borders in the US Agrawal (2015) and the Röstigraben in Switzerland Eugster and Parchet (2014), resuming the study of fiscal interdependencies among jurisdictions.

In sum, this article primarily contributes to the emerging quasi-experimental literature on strategic tax interdependence among local governments. It adds to the findings in Agrawal (2015) and Eugster and Parchet (2014) by causally identifying tax mimicking in local business taxation in Portugal. To my knowledge, it is the first study that provides significant causal inference on yardstick competition, though it depicts this regulatory mechanism as a short-term out-of-equilibrium phenomenon in the context of local politics. Also, this paper contributes to the literature on the impact of information on yardstick competition. In line with the spatial studies by Revelli (2006) and Bivand and Szymanski (1997), this article argues that information mitigates yardstick competition. The main difference of this study is its reliance on a quasi-experimental methodology that lends itself to causal interpretation. Finally, it provides a contribution to the literature on voting behaviour to the extent that it fails to uncover retrospective voting in local politics. 


\section{Empirical Setting}

\subsection{Institutional Background}

Continental Portugal comprises 278 municipalities $3^{3}$ Municipalities constitute the first subnational level of government and are responsible for several aspects of the local public administration, including the supply of public goods and regional development. For the purpose, municipalities have their own finances, assets, and personnel.

There are two elected bodies at the municipal level: the executive council, and the legislative assembly. Local elections for both institutions take place simultaneously countrywide every four years within a proportional representation system of closed lists with seats distributed according to the D'Hondt method. The mayor and another 10-14 council members constitute the municipal council; its exact size depends on local population size. There are no direct elections for the mayoral position. Instead, the first name on the list that gathers the highest number of votes in the race for the local council becomes the mayor. Despite the proportional seat allocation rule, the winning list holds the executive power, while councillors of the opposition are often assigned non-executive roles. Executive decisions are usually summarily approved by the municipal assembly; thus, mayors enjoy plenty of policy discretion.

Vertical transfers from the central government and European institutions constitute the primary source of municipal revenue - on average, over $50 \%$ of the budget. Revenues from local taxes and user fees, however, are growing in importance with the introduction of reforms pushing for revenue decentralisation and an increase in local tax autonomy 4 One such reform, Law no. 2/2007 in effect since 1 January 1 2007, increased local tax autonomy

\footnotetext{
${ }^{3}$ For increased comparability, I focus on the continental region and leave out the 30 municipalities in the autonomous regions of Azores and Madeira.

4 The degree of tax autonomy is still low; municipalities cannot create new taxes, and the central government always decides on the tax base. Most often municipalities choose the applicable tax rate within a centrally defined range.
} 
by introducing a local business tax $5^{5}$ The same law also reformed other aspects of local financing; two of the most critical changes include the introduction of a local income tax and adjustments to the allocation formula of vertical transfers between municipalities. In the empirical analysis, I control for both changes.

The local business tax substituted a pre-existing municipal business surcharge (Derrama) $!^{6}$ The latter was an extraordinary source of capital revenue only available to municipalities involved in financial stability pacts or in need of an increase in fiscal capacity for specific investments. The surcharge could vary within the range of $0-10 \%$ of the national corporate tax (Imposto sobre o Rendimento de Pessoas Colectivas, IRC) and should be communicated to the Tax and Customs Authority (Autoridade Tributária e Aduaneira) by 31 October of the year before tax revenue collection. During the period under analysis, the IRC amounted to $25 \%$ of taxable profit excluding deductions. Thus, the surcharge corresponded to a maximum effective tax rate of $2.5 \%$.

In contrast, the local business tax has a universal character; it is unconditionally available to all municipalities. Also, it is independent of the IRC; the law defines the tax base as the taxable business income apportioned to the jurisdiction before deductions. A singlefactor formula allocates income to municipalities according to their payroll ratio against the total payroll. The increase in the tax base motivated a decrease in the range of possible tax rates. The municipal council can choose a local business tax within the interval $0-1.5 \%$ and must communicate the decision to the Tax and Customs Authority by 31 December of the year before tax revenue collection, otherwise the zero default applies.

There are two main differences between the municipal surcharge and the local business tax. First and foremost, the local business tax is, contrary to the surcharge with its conditional character, a new source of municipal financing. Revenues from the local business

\footnotetext{
${ }^{5}$ Law no. 2/2007 in Diário da República 10, Series I, 15 January 2007.

${ }^{6}$ The municipal business surcharge ceased to exist in 2007 with the introduction of the local business tax.
} 
tax accrue to the current revenues account; current revenues finance the day-to-day business of the municipality. Revenues from the surcharge were capital revenues intended for investment decisions. Experts predicted this change to increase the number of municipalities relying on capital taxation. Second, the local business tax is independent of the IRC. In fact, companies may not have to pay IRC if deductions eliminate all taxable business profits, but they may still be liable to pay the local business tax. The rationale for this is that the local business tax should compensate municipalities for their investment in the local infrastructure necessary to support business activities. This investment takes place independently of business profits.

\subsection{To Tax or Not to Tax}

There are several reasons why municipalities may or may not levy the local business tax. Taxation is a heated topic in Portugal with property and business taxation at the forefront of the discussion at the local level. Thus, levying the local business tax may entail electoral concerns. Such concerns can lead to yardstick competition in local business taxation. Even though the local property tax is the primary fiscal instrument at the local level and thus the most contested, there are at least two reasons for voters to oppose the local business tax. First, it usually disproportionately affects small and medium-sized companies which comprise about $60 \%$ of the business landscape in Portugal. These companies are often in financial distress and advocate a reduction in the local tax burden. Second, a single-factor formula apportions the local business tax according to the payroll ratio of a municipality which relates to another critical issue in Portugal: the level of employment. Even though small companies are unlikely to move production or storage facilities due to local business taxation, firms with more than one production or storage facility may efficiently optimise their overall payroll ratio to avoid taxes. 
The last consideration relates to the theory of tax competition. Tax competition may provide further reasons for or against local business taxation. If certain municipalities benefit from agglomeration effects, they may raise the tax without losing the tax base. Conversely, municipalities may choose not to levy the tax to attract more companies. Concerns regarding tax competition in the local business tax in Portugal are, however, limited. The maximum tax differential among municipalities is $1.5 \%$; this differential is relatively small when compared to the national business tax amounting to $25 \%$ of taxable profits. Also, by law mayors decide on the local business tax rate annually, meaning that any differentials may be short-lived. Moreover, the change in the apportionment formula by the central government in 1993, from the headquarter location to payroll ratio, was meant to preempt tax competition. 7

If municipalities compete over expenditure instead, mayors may decide for local business taxation to increase the current account budget and provide more or better municipal services. The revenues from the local business tax, however, do not constitute a major part of the available budget - on average, $2 \%$. Thus, any potential increase in expenditure may be too small to motivate local business taxation or to result in significant changes in expenditure policy.

Spillover effects have little relevance within the context under study. Benefit spillovers from municipalities levying the local business tax and investing in municipal services are limited as most of these are confined to residents. This mechanism would, nonetheless, create a negative interdependence in tax setting, meaning that municipalities would be unlikely to raise the local business tax. Negative spillovers, in contrast, could lead to jurisdictions raising the local business tax. However, extrapolation from the data on the pre-reform period suggests no negative spillovers as the number and identity of the municipalities relying on the business surcharge remains stable over the years.

\footnotetext{
${ }^{7}$ Decree-Law no.37/1993 in Diário da República 37, Series I, February 13, 1993.
} 
Finally, social learning could be one of the main reasons behind local business taxation. Mayors are dealing with a new fiscal instrument with which they have no prior experience and little knowledge of the consequences. Local business taxation may thus result from both observation and experimentation by municipalities.

\section{$2.3 \quad$ Data}

For this study, I combined data on electoral and financial outcomes at the Portuguese municipal level for the period 2005-2013. This sample period encompasses three pre- and six post-reform years; the year 2007 belongs to the pre-reform period since local business tax revenue collection occurs for the first time in 2008. The more extended post-reform period allows me to study the short- and long-run treatment effects. Additionally, the sample period includes three local elections that took place in 2005, 2009, and 2013. I use electoral outcomes to study how electoral results influence tax setting and vice-versa.

The primary outcome variables in this study are the probability of levying the local business tax, the local business tax rate, and the local business tax revenues. I measure the likelihood of imposing the local business tax with a dummy that is equal to one for every municipality-year observation in which the tax rate is positive and zero otherwise. The local business tax rate corresponds to the precise rate chosen by the municipality in each year. Tax revenues refer to the log-transformed revenue from the local business tax accruing to each jurisdiction.

Data on local tax rates and local finances are available online at the General Directorate for Local Authority (Direcção Geral das Autarquias Locais) and the Tax and Customs Authority websites for the entire sample period. I deflated tax revenues, and other flow variables used as controls, to the year 2015 using the national consumer price index from the World Economic Outlook Database of the International Monetary Fund. In the empirical 
analysis, I always rely on per capita values obtained using a measure of resident population per municipality from the Portuguese National Statistics Institute (INE).

Local election outcomes are available online at the National Electoral Commission (Comissão Nacional de Eleições) and the General Directorate for Internal Affairs (Direcção Geral da Administração Interna) websites. Data report the number of votes and seats allocated to each of the parties running for the local elections in each municipality. Using these data, I created two main political variables: the probability of re-election and the victory margin. The first is a dummy equal to one if the incumbent party wins the election and zero otherwise. The second is the difference in the vote share between the winner and runner-up for each municipality and election.

For robustness, I rely on a vector of control variables. The vector includes measures of municipal revenues, population size, and economic activity, as well as political dummies indicating whether there is a majority in the local council and if the mayor is left-leaning. Municipal revenue variables include revenues from other taxes and fees at the discretion of the local executive as well as transfers from the central government. The political variables are defined based on the local electoral results for the municipal council. Municipal population size coincides with the resident population per municipality series from INE. Finally, the measure of local economic activity is proxied by night-light output over the years under study.

\section{Identification Strategy}

The introduction of the local business tax in Portugal provides an optimal setting to analyse local tax interactions. Contrary to other quasi-experimental investigations (see, e.g.Isen (2014) or Lyytikainen (2012)), the reform has a direct impact on the jurisdictions under study. Nonetheless, I need to take into account some particular features of the present 
setting. First, even though every municipality abides by the same rules, the pre-existence of a local business surcharge available only to some jurisdictions creates two distinct groups. One group that has experience with local business taxation - even if in the form of a surcharge - and another that the reform endowed with a business tax instrument for the first time in 2007.

In all likelihood, the introduction of the local business tax did not have the same impact on the two sets of municipalities; thus, the two groups are not comparable. In fact, the majority of jurisdictions collecting the surcharge in the pre-reform period transitioned into the new regime merely by substituting the surcharge with the tax - this happened in 149 of 161 municipalities. Figure (1) depicts the average trend in the tax rate for the two groups. In the pre-reform period, the municipalities relying on the surcharge chose, on average, a tax rate close to the upper bound of $10 \%$, which translates into an effective tax rate of 2.5\%. From 2008 onwards, this set of municipalities, on average, substituted the surcharge with the local business tax at a rate close to the new maximum of $1.5 \%$. The second group of municipalities, on the other hand, did not collect the surcharge and, in the aftermath of the reform, has an average tax rate that is only slightly above zero.

Due to selection concerns and to ensure comparability, I drop the municipalities that collected the surcharge from the analysis. This sample restriction reduces the number of jurisdictions under study from 278 to 117 but allows for causal interpretation of the coefficient estimates under weaker identifying assumptions. Figure (2) shows the municipalities included in the sample. The excluded municipalities nevertheless play a crucial role in the identification of tax mimicking.

Since the reform entered into effect at the same time across the country, the identification strategy explores heterogeneity in treatment intensity to establish the control and treatment groups. Following Janeba and Osterloh (2013), who show how small jurisdictions interact with their neighbours, I rely on geographic proximity. More specifically, I rely on 
neighbourliness: I divide municipalities into treatment and control based on whether they neighbour an excluded jurisdiction.

For robustness and to better grasp the dynamics of tax mimicking, I rely on three different measures of neighbourliness. First, I define it along contiguous borders; treated municipalities share a common border with an excluded jurisdiction. Second, in addition to sharing a common border, treated municipalities must lie within the same district as the neighbouring excluded jurisdiction. 8 This condition restricts the set of treated municipalities but increases comparability. Third, the treatment status depends on the kilometre distance between a municipality and its closest excluded neighbour. I use three critical distances: $10 \mathrm{~km}, 20 \mathrm{~km}$, and $30 \mathrm{~km}$. In practice, the centroid of a treated municipality lies within one of the three fixed intervals of the centroid of the closest excluded jurisdiction.

The identification strategy implicitly assumes that neighbourliness is random. If that is the case, I can assign any significant difference that emerges between neighbours and non-neighbours to the exogenous difference in treatment intensity and interpret the results causally. Neighboring municipalities, however, could differ in their propensity to levy the local business tax for several reasons. Nevertheless, there is no reason for the timing of the reform to coincide with a collective shock to the municipalities classified as neighbours; the law introducing a local business tax was voted and imposed by the central government and is, thus, exogenous to the local governments.

To test the identifying assumptions and guarantee a causal interpretation of the estimates, I rely on the outcomes from means comparison and balance checks in the spirit of Pei et al. (2016). These checks work as placebo tests to verify whether there are observable differences between treatment and control municipalities. I provide the results for an extensive list of local observable characteristics ranging from socio-economic to political

${ }^{8}$ An alternative but similar definition is to classify as neighbours municipalities that in addition to sharing a common border also belong to the same economic region as the excluded neighbouring municipality. Both definitions lead to similar results. 
variables. 9 Results show no significant differences between treatment and control for all variables under study.

Finally, to positively reduce concerns regarding omitted variable bias, I estimate regression models that always include municipality fixed effects. These control for invariant municipality-specific characteristics and should satisfy any further concerns with the exogeneity of neighbourliness. Also, I control for time effects through three different approaches: year fixed effects, district trends, and district-year fixed effects. The three methods control for time-specific shocks common to all municipalities, region-specific trends in the outcome variables, and the latter provide the most conservative estimation by controlling for unobservable district characteristics that vary over time.

\section{Tax Mimicking}

\subsection{Empirical methodology}

I exploit, within a diff-in-diff design, the heterogeneity in treatment intensity coming from the geographic proximity of municipalities to the jurisdictions collecting the business surcharge in the pre-treatment period to identify interactions in tax setting among local governments. I must rely on heterogeneous treatment intensity because the law that introduced the local business tax entered into force in all jurisdictions at the same time. By dividing the municipalities into treatment and control, I can control for time-specific events that could affect the results; in particular, I can control for other aspects of the 2007 local finances reform.

In the first step of the empirical analysis, I study the existence of tax mimicking in local business taxation, i.e.whether neighbour municipalities are more likely than nonneighbour to levy the local business tax. Within a diff-in-diff methodology, the difference

\footnotetext{
9 See Tables A.1 and $\mathrm{A.2}$ in the Appendix.
} 
in the change in the outcome variable between treatment and control groups from the preto the post-reform period identifies the average treatment effect.

Formally, let $N_{i}$ be a dummy indicating treatment, equal to one for all neighbouring municipalities and zero otherwise. Law no. 2/2007, regulating local business taxation entered into force retroactively on 1 January 2007, i.e. $t_{0}=2007$. However, the proceeds from the first local business tax rate chosen in 2007 are transferred to the municipality only in 2018. Thus, let $d_{t}$ be a time dummy indicating the post-reform period, that switches to one in 2008 , such that $d_{t}=1\left[t>t_{0}\right]$. I causally identify strategic tax setting within the following general diff-in-diff regression model:

$$
Y_{i t}=\gamma_{i}+\gamma_{t}+\delta\left(N_{i} \cdot d_{t}\right)+Z_{i t}^{\prime} \beta+\gamma_{s} \cdot t+\gamma_{s t}+\epsilon_{i t}
$$

where $Y_{i t}$ refers to each of the outcome variables, $E_{i t}=\left(N_{i} \cdot d_{t}\right)$ indicates treatment, i.e.the neighbour municipalities in the post-reform period, and $Z_{i t}^{\prime}$ is the vector of control variables described in the previous section. The model always includes municipality fixed effects, $\gamma_{i}$. Additionally, different versions of the model rely on year fixed effects, $\gamma_{t}$, district trends, $\gamma_{s} \cdot t$, or district-year fixed effects, $\gamma_{s t}$. The parameter $\delta$ measures the average treatment effect, identifying strategic tax setting.

I distinguish short- from long-term treatment effects by estimating the regression model using two different samples: one that restricts observations to the years 2005-2010, and another that relies on the entire sample period 2005-2013. Moreover, to complement the study of average treatment effects, I estimate yearly average treatment effects within the following extension of the diff-in-diff regression model to identify the pattern of lagged effects.

$$
Y_{i t}=\gamma_{i}+\gamma_{t}+\sum_{\tau=1}^{m} \delta_{-\tau} E_{i, t-\tau}+Z_{i t}^{\prime} \beta+\gamma_{s} \cdot t+\gamma_{s t}+\epsilon_{i t}
$$


The sum in Equation (2) allows for $m$ lags or post-treatment effects. The number of lags is $m=6$, one for each of the six years of the post-reform period, 2008-2013. The remaining variables are defined as before.

\subsection{Descriptive evidence and regression results}

Figure (3) shows the average business tax rate in treatment and control municipalities over the sample period. This graph relies on the within-district definition of neighbourliness which is the preferred definition for two reasons. The first reason is that it captures historical ties between jurisdictions, whereas the second relates to the fact that it provides a better balance between treatment and control units compared to the other definitions (80 to 37 municipalities). ${ }^{10}$

Neighboring municipalities appear more likely to levy the tax after 2007. Control municipalities follow, to a smaller extent, in 2009. However, by 2012 both treatment and control municipalities charge similar average local business tax rates. To the extent that means are informative, there appears to be short-term tax mimicking in local business taxation which dissipates over time, with the increase in business taxation by non-neighbours.

Table 1 collects the regression results relying on the contiguous and within-district definitions of neighbourliness from the estimation of the most conservative version of Equation (1), including municipality and district-year fixed effects as well as the vector of control variables. The first line lists the outcome variables under study. 11 Models (I), (III), and (V) refer to the short-term analysis with sample period between 2005-2010. Models (II), (IV), and (VI) rely on the full sample, 2005-2013, to assess the long-run treatment

\footnotetext{
${ }^{10}$ The within-economic region definition of neighbourliness gives the same balance between treatment and control, while the contiguous neighbours definition classifies 97 out of 117 municipalities as treated. The fixed distance definition of neighbourliness defines 13, 70, and 97 out of 117 jurisdictions as treated for the $10 \mathrm{~km}, 20 \mathrm{~km}$, and $30 \mathrm{~km}$ fixed distances.

${ }^{11}$ All regression results in the paper are estimated within the most conservative specification of the regression models. Results are robust to different specifications, relying on year fixed effects and district trends; these are available upon request.
} 
effects. For the within-district definition of neighbourliness, all models include two mutually exclusive treatment dummies: one identifies contiguous neighbours that lie within the same district as the neighbouring excluded municipality, and the other indicates all jurisdictions that qualified as neighbours according to the contiguous borders definition of neighbourliness but belong to a different district.

Regression results provide evidence of tax mimicking in local business taxation. For the contiguous neighbours, the magnitude and significance of the coefficient estimates are similar for the short- and long-term analysis. These results appear to be driven by same district neighbours in the short run and different district neighbours in the long run. In the short run, within-district neighbours are 14 percent more likely to levy the local business tax, the tax rate is significantly higher by close to 0.2 percentage point, and they raise around 28 percent more revenues from local business taxation. In the long run, however, the magnitude of each of these effects drops for within-district neighbours while it increases for different district neighbours. These results suggest a spatial diffusion in local business taxation over time.

In Table 2, I collect the results for the alternative definition of neighbourliness based on kilometre distance. Coefficient estimates rely on neighbourliness within critical intervals of $10 \mathrm{~km}, 20 \mathrm{~km}$, and $30 \mathrm{~km}$ as follows. A municipality is classified as a neighbour if its centroid lies within the radius of the specific fixed distance from the centroid of the closest excluded jurisdiction. To introduce a dynamic time dimension into this approach, the sample period increases in the critical distance. Model (I), defines treated municipalities as the ones within $10 \mathrm{~km}$ of an excluded jurisdiction and relies on a sample period restricted to only one post-reform year, encompassing the years 2005-2008. Model (II), where the critical distance is $20 \mathrm{~km}$, uses a sample including two years of the post-reform period, 2005-2009. Finally, models (III) and (IV) that rely on a critical distance of $30 \mathrm{~km}$ use the short- and long-term sample periods. The hypothesis is that the closer the municipality 
is to its excluded neighbour, the more exposed it is to local business taxation. I assume that the degree of exposure encompasses greater distances over time as more municipalities become familiar with the local business tax through observation or experience. As before, the table provides the coefficient estimates for the most conservative version of Equation (1).

Coefficient estimates provide additional significant evidence of tax mimicking, reinforcing the previous results. The spatial and time dimensions of the distance regressions also suggest a diffusion in local business taxation from the closest to the farthest neighbouring municipalities over time. Coefficient estimates for the most restrictive definition of neighbourliness are of a higher magnitude and are more significant than for any of the alternatives. Neighbours within 10km of an excluded municipality are 27 percent more likely to levy the local business tax in the year after the introduction of the reform. Moreover, the tax rate is on average 0.4 percentage point higher, and revenues are also significantly higher. For the $20 \mathrm{~km}$ and $30 \mathrm{~km}$ distant neighbours, the magnitude and significance of the coefficients are in line with the previous results.

Finally, Figure 4 shows the yearly coefficient estimates of the treatment effect obtained by estimating Equation (2) using the contiguous borders definition of neighbourliness. The plots show the development of each of the three outcome variables for the entire sample period under study. Coefficient estimates are always significant until 2011; for the years 2012 and 2013 there is no longer a significant difference between neighbours and nonneighbours for any of the outcome variables. These results are, in all likelihood, due to the increase in local business taxation by control municipalities in the long run. 


\section{$5 \quad$ Underlying Mechanisms}

\subsection{Yardstick Competition}

In their seminal work on political yardstick competition, Besley and Case (1995) formalise the Salmon (1987) model of horizontal competition by drawing the parallel between the franchised monopoly and regulator in Shleifer (1985) and the incumbent and electorate in local politics. Different industries, including the historical example of the activity-based reimbursement of hospitals, transport services such as railways in Japan or buses in Norway, or water utilities in Great Britain, apply yardstick competition as a regulatory mechanism. In local politics, however, evidence on yardstick competition is scarce.

The theory rests on performance benchmarking by the less informed party as a means to mitigate informational asymmetries, which in politics translates into retrospective voting (Salmon, 1987). However, the existing evidence on retrospective voting is inconclusive; the broad range of responsibilities that accrue to local governments is usually an obstacle to voting retrospectively (Oliver and Ha, 2007; Berry and Howell, 2007).

Here, I explore the link between strategic tax setting and electoral outcomes to test whether yardstick competition is the generating process behind local business taxation. Two questions guide the empirical analysis: first, who levies the local business tax?; and second, what is the impact of the tax on the incumbent's re-election probability and popularity?

To answer the first question, I rely on an extended version of the diff-in-diff model in Equation (1) that includes a second dummy variable indicating unpopular incumbents and its interaction with the main treatment variable $E_{i, t}$. I classify incumbents as unpopular depending on their margin of victory in the previous election. I estimate the results for two degrees of unpopularity. To this end, I use two dummy variables, the first indicating 
mayors that won the previous election with a victory margin of up to $5 \%$, and the second extending the cutoff to $10 \%$.

Formally, let $U_{i, t}$ be the dummy indicating unpopularity, equal to one for all unpopular mayors and zero otherwise. Underlying this dummy variable is the victory margin in the preceding election, $v_{i, t-1}$, with treatment depending on the value of the latter as follows, $U_{i, t}=1\left[v_{i, t-1} \in[0, h]\right]$, and $h=\{5,10\}$. I estimate the average heterogeneous treatment effects within the following regression framework:

$$
Y_{i t}=\gamma_{i}+\delta E_{i, t}+U_{i, t}\left(\alpha+\rho E_{i, t}\right)+Z_{i t}^{\prime} \beta+\gamma_{s t}+\epsilon_{i t}
$$

with all other variables defined as before. Table 3 provides the coefficient estimates. Results suggest that it is the popular mayors that engage in tax mimicking. Heterogeneous treatment effects for unpopular mayors are, in contrast to the average effect identified in the previous section, significantly negative.

To answer the second question, I restrict the sample to the local election years, 2005, 2009, and 2013. The outcome variables under study are the probability of re-election - a dummy variable indicating whether an incumbent was re-elected - and the incumbent's margin of victory.

I test the impact of local business taxation on the probability of re-election within the general diff-in-diff regression model in Equation (1), using the 2009 local elections as the short run and extending the analysis to the 2013 elections for the long-run results. Coefficient estimates, in panel A of Table 4, show no evidence of a consistent or significant impact of the tax variables on the probability of re-election for any of the elections.

I obtain an estimate of the impact of the three tax variables on the incumbent's popularity within a version of the extended diff-in-diff regression model in Equation (3). The dependent variable is the incumbent's margin of victory and the two treatments are de- 
fined as follows. The first measures in turns each of the three different tax variables, while the second is a dummy variable indicating re-election. The heterogeneous treatment effects measure the extent to which the margin of victory of an incumbent is affected by tax policy conditional on re-election 12 As before, regression results provide the short- and long-run treatment effects. Results in panel B of Table 4 show no significant impact of the local business tax on an incumbent's popularity. Heterogeneous effects are not significant for any of the tax variables or elections.

Overall, results suggest that local business taxation entails electoral concerns but no electoral consequences. In particular, popular mayors rely significantly more on the local business tax relative to unpopular mayors. The 2009 and 2013 local elections, however, show no significant impact of local business taxation on the probability of re-election. While this result could be due to the fact that only popular mayors levy the tax, the effect of local business taxation on the margin of victory is also insignificant.

The 2009 election results can, nonetheless, be explained by the fact that mostly treated municipalities relied on the local business tax, and were thus in line with the policies practiced in the neighbouring (excluded) jurisdictions. By the time of the 2013 elections, however, both treated and control municipalities relied on local business taxation, suggesting that voters did not punish mayors that did not conform to the benchmark set by neighbouring jurisdictions; thus, there is no evidence of retrospective voting based on local business taxation.

\subsection{Tax Competition}

Agrawal (2015) and Eugster and Parchet (2014) are thus far, to my knowledge, the only two quasi-experimental studies causally identifying tax competition. They find that strategic

\footnotetext{
12 I condition on re-election to track whether the local business tax has an impact on the margin of
} victory of the same party that levied the tax in the first place. 
tax interactions along state borders in the US and the Röstigraben in Switzerland constrain jurisdiction in their choice of tax policy. Their results are in line with the Bradford and Oates (1971) definition of tax competition predicting that local governments will produce too low a level of public goods due to a collapse of the tax rates.

This race to the bottom rationale, however, does not match the present evidence. In contrast, regression results point instead to a race to the top, usually the result of agglomeration economies (Baldwin and Krugman, 2004) 13 However, as shown in the means and balance tests, there appear to be no differences between treatment and control municipalities regarding the overall economy suggesting that the agglomeration hypothesis is unlikely to explain the previous results. Thus, in the presence of tax competition, the increase in the local business tax by neighbouring jurisdictions should drive out the mobile factors of production.

To test this hypothesis, I regress the following outcome variables, the municipal business volume and the number of companies in each municipality, on each of the tax variables under study. I collect the results for the short and the long run in subfigures (a), (b), (c), and (d) of Figure 5$]^{14}$ Estimates are obtained within a fixed effects model that includes municipality and district-year fixed effects, as well as the vector of control variables previously described.

The graphs show that none of the tax variables has an impact on the municipal business volume or the number of firms located in a municipality. These results thus fail to confirm the existence of tax competition in the present setting.

\footnotetext{
13 This section focuses on the literature on strategic complementarity in tax rates. However, a vast literature discusses tax rates as strategic substitutes. In fact, Parchet (2014) shows that tax rates are more likely strategic substitutes than complements.

${ }^{14}$ I provide the corresponding coefficient estimates in Table A.4 in the Appendix.
} 


\subsection{Expenditure Competition}

An alternative explanation for the regression results may be that local governments optimise over expenditure rather than tax rates (Koethenbuerger, 2011). Expenditure competition can lead to tax mimicking with increasing tax rates (Baicker, 2005). This hypothesis implies an increase in the expenditure level of municipalities levying the local business tax in the aftermath of the reform relatively to the pre-reform period and municipalities not collecting the tax.

To test this hypothesis, I follow the same procedure as in the previous section but use as the outcome variable the log-transformed per capita current local expenditures. I collect the results for the short and long run in subfigures (e) and (f) of Figure 5. As before, the graphs show no significant impact of levying the tax, the tax rate, or the revenues from the local business tax on the outcome variable under study. I thus also fail to identify any evidence of expenditure competition in the present setting.

\section{$5.4 \quad$ Negative Spillovers}

Spillover effects are another source of strategic interdependence identified in the literature (Galletta, 2017); these can be positive or negative. Positive spillovers occur if a municipality can benefit from services provided by other jurisdictions and may create a negative dependence on tax rates as a higher expenditure incurred by one jurisdiction reduces the spending need of another. Benefit spillovers are thus an unlikely candidate for generating tax mimicking at the local level.

Negative spillovers, on the other hand, can translate into a positive dependence on tax rates as municipalities need to counteract these externalities. For example, if a jurisdiction invests in fighting crime by increasing the policing budget, criminals may move to neighbouring areas thus creating the need for increased policing also in these. Or, if a mu- 
nicipality provides above-average services, others may need to raise tax rates to compensate for the flight of residents to that jurisdiction.

In this section, I study whether negative spillover effects motivate tax mimicking in the present setting. To this end, I examine whether treatment effects are robust to excluding municipalities that have a relatively higher exposure to excluded jurisdictions. Arguably, in the presence of negative spillover effects the most affected municipalities, i.e.the ones with the highest treatment intensity, are those surrounded by neighbours that used to levy the municipal business surcharge.

I re-estimate the most conservative version of Equation (1) for two different samples using the contiguous borders definition of neighbourliness. In the first sample, I exclude all jurisdictions surrounded by excluded municipalities, i.e.whose every neighbour is an excluded jurisdiction. The second sample follows the same logic: I drop all municipalities for which over half the number of neighbours are excluded municipalities. Regression results in panels $\mathrm{A}$ and $\mathrm{B}$ of Table 5 are in line with the baseline results, indicating that the treatment effects do not hinge on specific municipalities that are overexposed to excluded jurisdictions. To this extent, I find no evidence that tax mimicking is a result of negative spillover effects.

\subsection{Social Learning}

Becker and Davies (2014) recently suggested a new explanation for tax mimicking based on social learning. Their learning-based model of tax policy diffusion relies on incomplete information, which can be overcome through the observation of policy choices by other agents. In contrast to yardstick competition, social learning should not entail electoral concerns.

Given the novelty of the local business tax for the municipalities included in the sample, mayors may have followed the policies of more experienced neighbours, leading to tax 
mimicking. Identifying social learning, however, is an empirical challenge. To my knowledge, only Glick (2012) provides anecdotal evidence based on interviews with colleges and university attorneys on the effects and determinants of policy knowledge diffusion through social learning.

In this section, I test the social learning hypothesis by assuming that policy diffusion is based on geographical location. Arguably, being close by excluded municipalities translates into a higher exposure and perhaps a better understanding of the new tax instrument (Berry and Baybeck, 2005; Shipan and Volden, 2006). To test for social learning, in addition to identifying the neighbouring municipalities as before, I also identify the new neighbours that emerge every time a jurisdiction in the sample decides to levy the local business tax. Thus, every year, there is a new set of neighbours that according to the social learning literature should be more likely to impose a local business tax relative to the remaining non-neighbouring municipalities.

Formally, I test for social learning by estimating the following extension of the baseline diff-in-diff regression model:

$$
Y_{i t}=\gamma_{i}+\gamma_{t}+\delta E_{i, t}+\sum_{\tau=2009}^{2013} \delta_{\tau} L_{i, \tau}+Z_{i t}^{\prime} \beta+\gamma_{s} \cdot t+\gamma_{s t}+\epsilon_{i t}
$$

where the sum refers to dummy variables that correspond to each year from 2009 to 2013 and identify the new neighbouring municipalities exposed to local business taxation. All remaining variables are defined as before.

I obtain the coefficient estimates in Table 6 within the most conservative specification of Equation (4). Models (I), (III), and (V), provide the short-run results, while models (II), (IV), and (VI) extend the analysis to 2013. Coefficient estimates do not support the social learning hypothesis as defined in this section. There is no evidence of a pattern in policy diffusion among the new yearly sets of neighbours. 


\section{Discussion}

The introduction of a business tax at the local Portuguese level in 2007 provides the ideal laboratory for the study of strategic fiscal interactions among municipalities. I rely on a comprehensive database on electoral and financial outcomes for 117 jurisdictions over the period 2005-2013. My identification strategy that on an exogenous reform, a quasiexperimental diff-in-diff methodology, and heterogeneity in treatment intensity to causally identify tax mimicking and its generating process.

The link between tax mimicking and electoral outcomes, followed by a long-run change in behaviour consistent with the information provided by the local elections, points to yardstick competition in local business taxation. The business tax is a visible topic in local electoral campaigns despite its small economic size. It is possible that inexperienced mayors rely on both benchmarking and ensure room for damage control concerning the vote margin. Voters, however, do not appear to judge the quality of the mayor based on business taxation. This information, made clear during the local elections, may have led to the general diffusion of local business taxation among jurisdictions. Apart from electoral concerns, I find no evidence of other generating processes of tax mimicking.

Local business taxation does not have a significant impact on municipal business volume or the number of firms located in a municipality. These results may be due to the small magnitude of the local business tax rate. When compared to the national corporate tax rate set at $25 \%$ of the taxable profit, the impact of the local tax on corporate decisions is arguably low as any tax differential between municipalities gives them little room to poach for each other's tax base. Also, local governments can change the tax rate annually. Hence, any existing tax differentials may be short-lived, which reduces the incentives for companies to relocate. Moreover, the single-factor formula apportionment based on the 
payroll ratio complicates the relocation process. Finally, small companies, which are more likely to be vulnerable to local business taxation, usually benefit from a reduced tax rate.

I also do not find significant evidence of expenditure competition nor negative spillover effects. These results may be explained by the magnitude and narrowness of the local business tax revenues. The absence of expenditure competition may be because the revenues raised through the local business tax are of too small a magnitude to produce significant effects or motivate competition. The absence of spillover effects is probably due to the low magnitude of the revenues together with the fact that current expenditures are targeted and are unlikely to produce significant externalities.

Even though I do not find evidence of social learning as hereby defined, the setting under study provides a context of observation and experimentation by mayors. I do not claim that this is not undergoing; however, I discard this option on the basis that pure social learning should not entail electoral concerns which are present in this setting.

\section{Acknowledgments}

I thank Thushyanthan Baskaran, Ernesto Dal Bó, Albert Solé-Ollé, and seminar participants at the CESifo Area Conference on Public Sector Economics (Munich, 2017), the ZEW Research Seminar and Conference on Public Finance (Mannheim, 2017), the IEB Workshop on Political Economy and Fiscal Federalism (Barcelona, 2017), and the International Institute of Public Finance (IIPF Tokyo, 2017).

\section{References}

Agrawal, D. R. (2015). The tax gradient: Spatial aspects of fiscal competition. American Economic Journal: Economic Policy 7(2), 1-29. 
Baicker, K. (2005). The spillover effects of state spending. Journal of Public Economics 89, $529-544$.

Baldwin, R. E. and P. Krugman (2004). Agglomeration, integration, and tax harmonisation. European Economic Review 48, 1-23.

Baskaran, T. (2014). Identifying local tax mimicking with administrative borders and a policy reform. Journal of Public Economics 118, 41-51.

Becker, J. and R. B. Davies (2014). Learning and international policy diffusion - The case of corporate tax policy. CESifo Area Conference on Public Sector Economics.

Berry, C. R. and W. G. Howell (2007). Accountability and local elections: Rethinking retrospective voting. Journal of Politics 69(3), 844-858.

Berry, W. D. and B. Baybeck (2005). Using geographic information systems to study interstate competition. American Political Science Review 99(4), 505-519.

Besley, T. and A. Case (1995). Incumbent behavior: Vote-seeking, tax-setting, and yardstick competition. American Economic Review 85(1), 25-45.

Bivand, R. and S. Szymanski (1997). Spatial dependence through local yardstick competition: Theory and testing. Economic Letters 55, 257-265.

Bradford, D. and W. Oates (1971). The analysis of revenue sharing in a new approach to collective fiscal decisions. Quarterly Journal of Economics 85(3), 416-439.

Brueckner, J. (2003). Strategic interaction among governments: An overview of empirical studies. International Regional Science Review 26(2), 175-188.

Case, A. C., H. S. Rosen, and J. R. Hines (1993). Budget spillovers and fiscal policy interdependence. Journal of Public Economics 52, 285-307. 
Eugster, B. and R. Parchet (2014). Culture and taxes: Towards identifying tax competition. R\&R Journal of Political Economy.

Galletta, S. (2017). Law enforcement, municipal budgets and spillover effects: Evidence from a quasi-experiment in Italy. Journal of Urban Economics 101, 90-105.

Gibbons, S. and H. G. Overman (2012). Mostly pointless spatial econometrics. Journal of Regional Science 52, 172-191.

Glick, D. M. (2012). Learning by mimicking and modifying: A model of policy knowledge diffusion with evidence from legal implementation. Journal of Law, Economics, and Organization 30(2), 339-370.

Isen, A. (2014). Do local government fiscal spillovers exist? Evidence from counties, municipalities, and school districts. Journal of Public Economics 110, 57-73.

Janeba, E. and S. Osterloh (2013). Tax and the city - a theory of local tax competition. Journal of Public Economics 106, 89-100.

Koethenbuerger, M. (2011). How do local governments decide on public policy in fiscal federalism? Tax vs expenditure optimization. Journal of Public Economics 95, 15161522.

Lyytikainen, T. (2012). Tax competition among local governments: Evidence from a property tax reform in Finland. Journal of Public Economics 96, 584-595.

Manski, C. F. (2000). Economic analysis of social interactions. Journal of Economic Perspectives 14(3), 115-136.

Oliver, J. E. and S. E. Ha (2007). Vote choice in suburban elections. American Political Science Review $101(3), 393-408$. 
Parchet, R. (2014). Are local taxes strategic complements or strategic substitutes? R\&R American Economics Journal: Economic Policy.

Pei, Z., J.-S. Pischke, and H. Schwandt (2016). Poorly measured confounders are more useful on the left than on the right. Mimeo.

Revelli, F. (2006). Performance rating and yardstick competition in social service provision. Journal of Public Economics 90, 459-475.

Salmon, P. (1987). Decentralisation as an incentive mechanism. Oxford Review of Economic Policy 3(2), 24-43.

Shipan, C. R. and C. Volden (2006). Bottom-up federalism: The diffusion of antismoking policies from U.S. cities to states. American Journal of Political Science 50(4), 825-843.

Shleifer, A. (1985). A theory of yardstick competition. Rand Journal of Economics 16(3), 319-327.

Wildasin, D. E. (1988). Nash equilibria in a model of fiscal competition. Journal of Public Economics 35(2), 229-240.

Wilson, J. D. (1986). A theory of interregional tax competition. Journal of Urban Economics 19(3), 296-315.

Wilson, J. D. and R. H. Gordon (2003). Expenditure competition. Journal of Public Economic Theory 5(2), 399-417.

Wilson, J. D. and D. Wildasin (2004). Capital tax competition: Bane or boon. Journal of Public Economics 88(6), 1065-1091.

Zodrow, G. R. and P. Mieszkowski (1986). Pigou, Tiebout, property taxation and the under-provision of local public goods. Journal of Urban Economics 19(3), 356-370. 


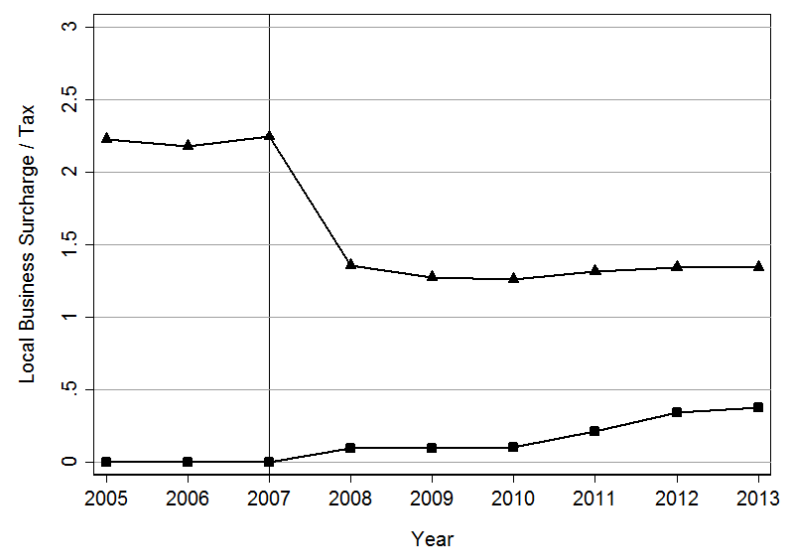

Figure 1: Municipal Surcharge and Local Business Tax. This figure provides a plot depicting the average trend in the municipal business surcharge and local business tax rate for two distinct groups of municipalities. The two groups are divided on the basis of whether they collected the surcharge in the pre-reform period. 


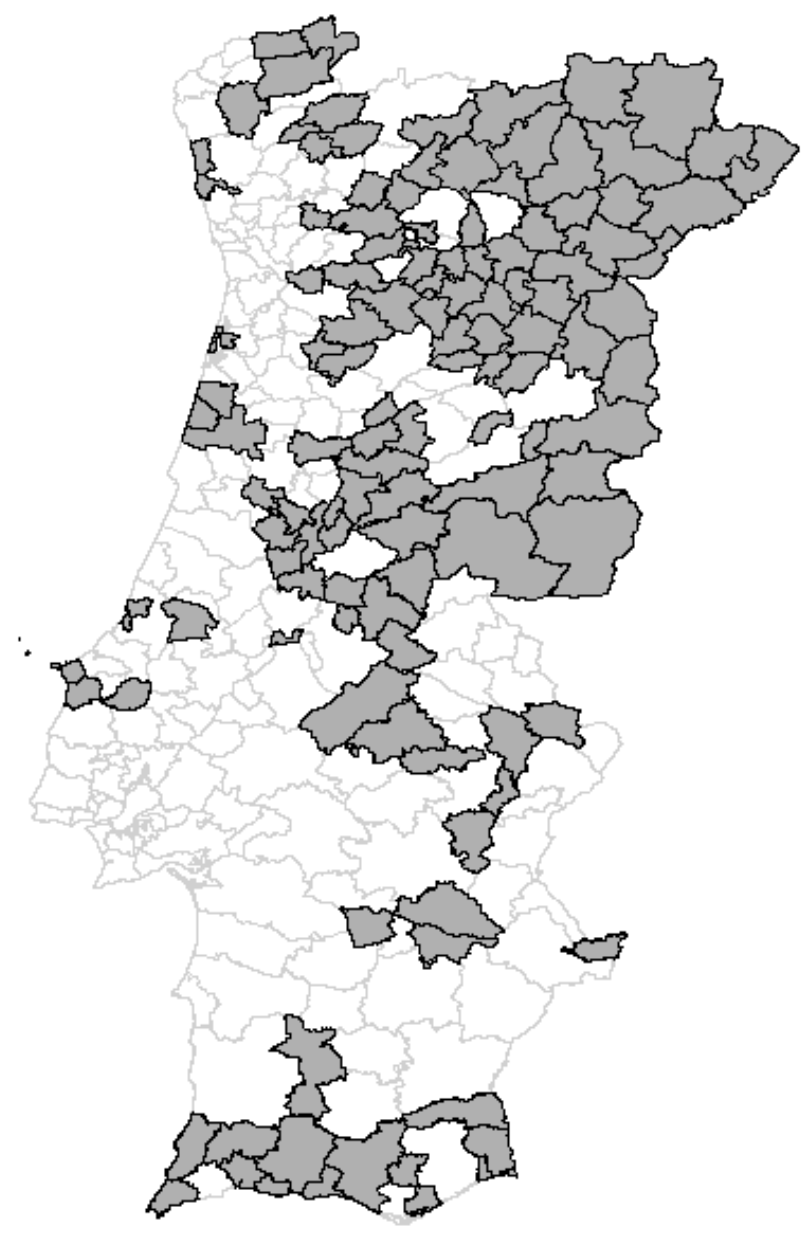

Figure 2: Municipalities included in the sample. This figure provides a map depicting the 117 municipalities that did not rely on the municipal business surcharge; these constitute the sample under study. 


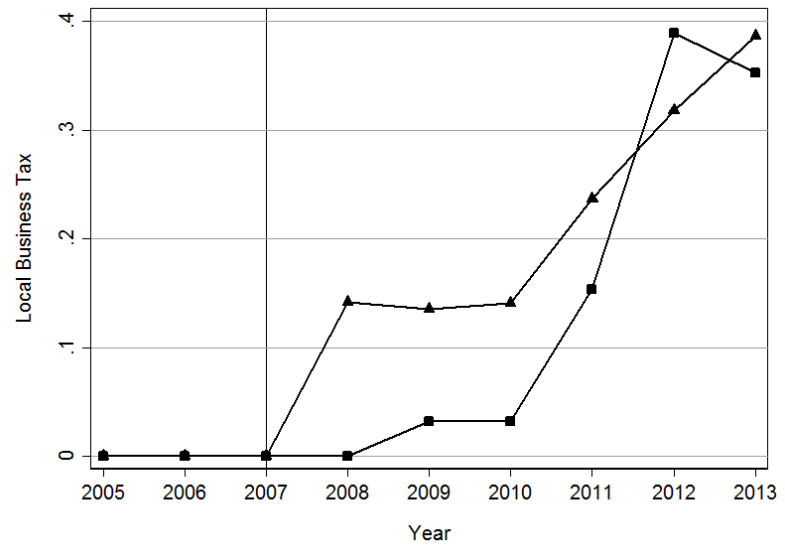

Figure 3: Local Business Tax. This figure provides a plot depicting the average trend in the local business tax rate in treated (triangle) and control (square) municipalities. 


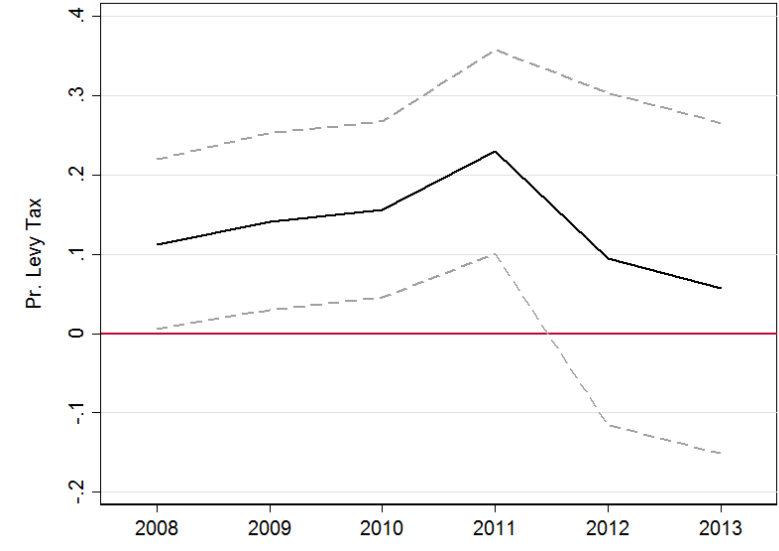

(a) Prob. Levy Tax

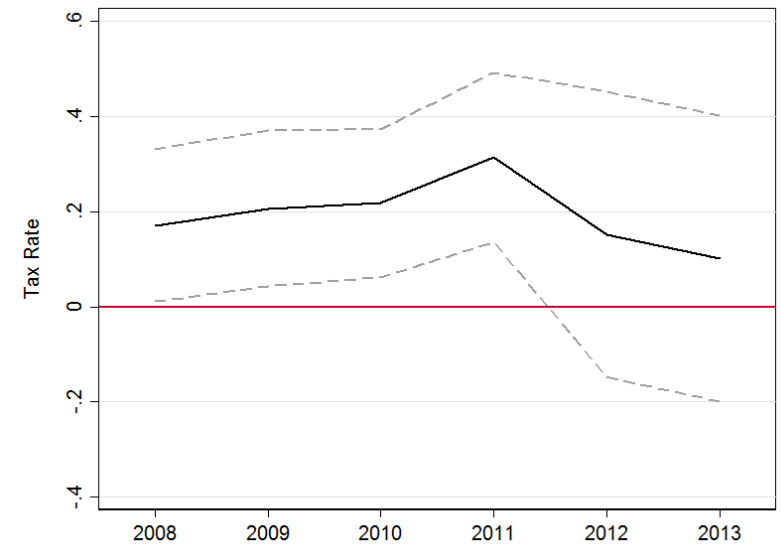

(b) Local Business Tax Rate

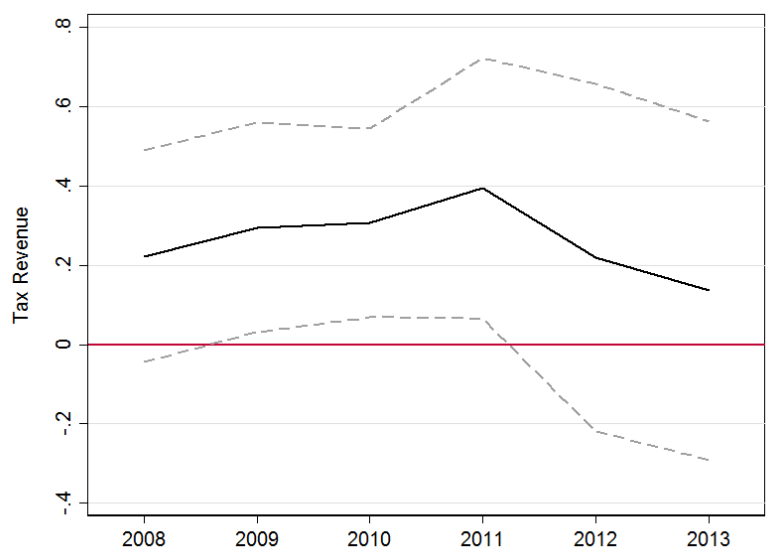

(c) Local Business Tax Revenue

Figure 4: Yearly Treatment Effects. This figure provides plots depicting the yearly average treatment effects for the three outcome variables: (a) the probability of levying the local business tax, (b) the local business tax rate, (c) the log of per capita local business tax revenue. Coefficient estimates are obtained within the most conservative version of Equation 22 that includes municipality and district-year fixed effects, and the vector of control variables. The dashed lines correspond to $95 \%$ confidence intervals. 


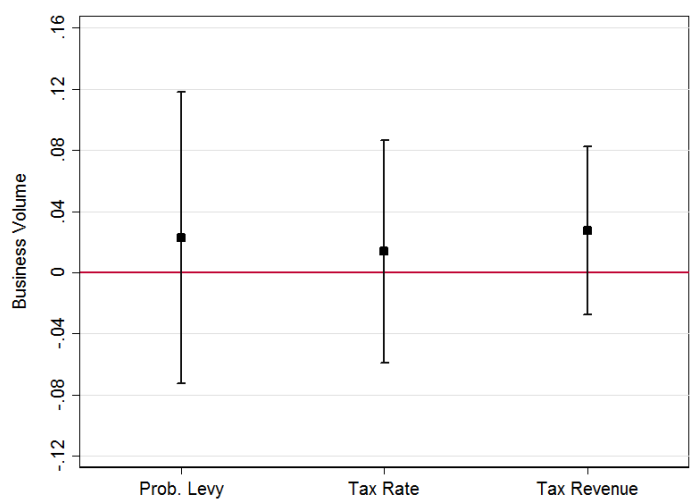

(a) Business Volume - Short-run

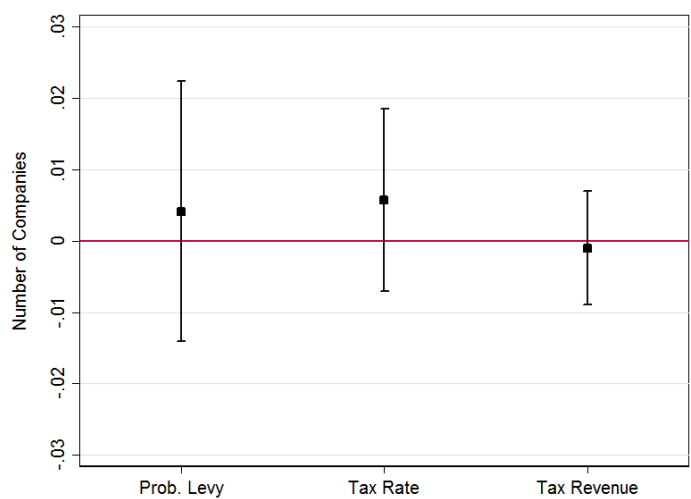

(c) No. of Firms - Short-run

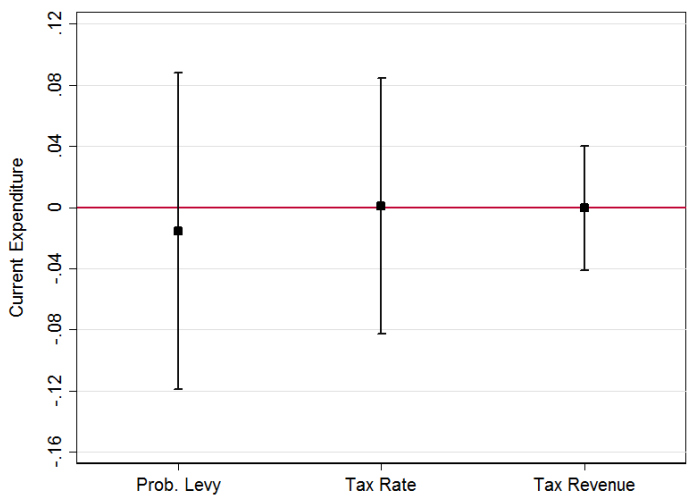

(e) Current Expenditure - Short-run

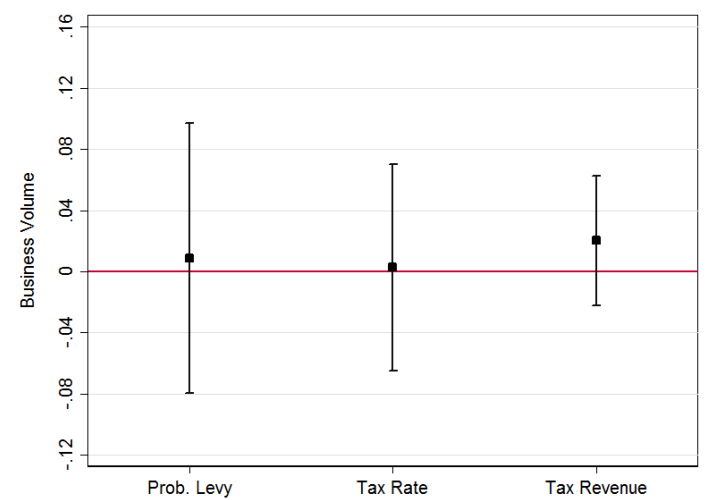

(b) Business Volume - Long-run

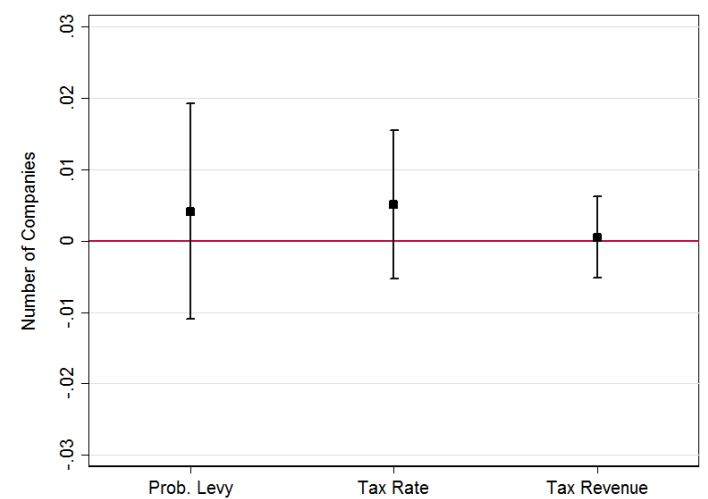

(d) No. of Firms - Long-run

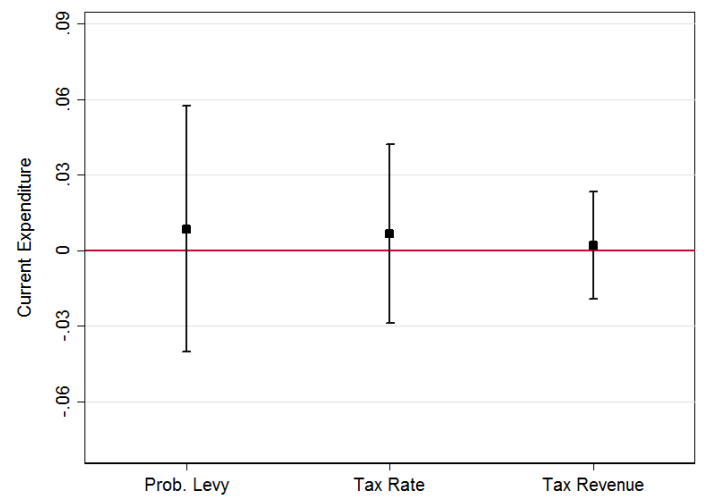

(f) Current Expenditure - Long-run

Figure 5: Tax and Expenditure Competition. This figure provides plots depicting the short- and long-run impact of levying the local business tax, the local business tax rate, and the local business tax revenues, on the municipal business volume (subfigures (a) and (b)), the number of firms located in a municipality (subfigures (c) and (d)), and the log of per capita of municipal current expenditure (subfigures (e) and (f)). Coefficients are obtained from the estimation of a fixed effects models regressing the outcome variables on each of the tax variables under study. All specifications include municipality and district-year fixed effects, and the vector of control variables. The capped lines correspond to $95 \%$ confidence intervals. 
Table 1: Tax Mimicking: Contiguous and Within-District Neighbors

\begin{tabular}{|c|c|c|c|c|c|c|}
\hline & \multicolumn{2}{|c|}{ Pr. Levy Tax } & \multicolumn{2}{|c|}{ Tax Rate } & \multicolumn{2}{|c|}{ Tax Revenue } \\
\hline & I & II & III & IV & $\mathrm{V}$ & VI \\
\hline \multirow{5}{*}{ Neighbors } & \multicolumn{6}{|c|}{ Panel A: Contiguous Neighbors } \\
\hline & 0.135 & 0.132 & 0.196 & 0.193 & 0.269 & 0.262 \\
\hline & $(0.053)$ & $(0.060)$ & $(0.078)$ & $(0.086)$ & $(0.124)$ & $(0.137)$ \\
\hline & {$[0.012]$} & {$[0.028]$} & {$[0.012]$} & {$[0.026]$} & {$[0.030]$} & {$[0.055]$} \\
\hline & & & Panel B: V & istrict $\mathrm{Ne}$ & & \\
\hline \multirow[t]{3}{*}{ District } & 0.137 & 0.128 & 0.201 & 0.190 & 0.283 & 0.274 \\
\hline & $(0.057)$ & $(0.063)$ & $(0.083)$ & $(0.091)$ & $(0.133)$ & $(0.145)$ \\
\hline & {$[0.016]$} & {$[0.040]$} & {$[0.016]$} & {$[0.036]$} & {$[0.034]$} & {$[0.059]$} \\
\hline \multirow[t]{3}{*}{$\neq$ District } & 0.122 & 0.150 & 0.166 & 0.205 & 0.193 & 0.192 \\
\hline & $(0.060)$ & $(0.088)$ & $(0.077)$ & $(0.117)$ & $(0.105)$ & $(0.143)$ \\
\hline & {$[0.043]$} & {$[0.088]$} & {$[0.031]$} & {$[0.079]$} & {$[0.065]$} & {$[0.180]$} \\
\hline District $\mathrm{x}$ year & Yes & Yes & Yes & Yes & Yes & Yes \\
\hline Controls & Yes & Yes & Yes & Yes & Yes & Yes \\
\hline Sample Period & 2005-10 & 2005-13 & $2005-10$ & 2005-13 & 2005-10 & $2005-13$ \\
\hline Observations & 702 & 1053 & 702 & 1053 & 702 & 1053 \\
\hline Municipalities & 117 & 117 & 117 & 117 & 117 & 117 \\
\hline
\end{tabular}

This table collects difference-in-differences regression results from the estimation of Equation (1) using the contiguous (Panel A) and within-district (Panel B) definitions of neighborliness. The dependent variables are indicated in the first row. All specifications include municipality fixed effects. Heteroscedasticity robust standard errors clustered at the municipal level in parentheses. P-values in brackets. 
Table 2: Tax Mimicking: Fixed Critical Distance Neighbors

\begin{tabular}{|c|c|c|c|c|}
\hline & \multicolumn{3}{|c|}{ Short-run } & \multirow{2}{*}{$\begin{array}{l}\text { Long-run } \\
\text { IV }\end{array}$} \\
\hline & I & II & III & \\
\hline \multirow{5}{*}{ Neighbors } & \multicolumn{4}{|c|}{ Panel A: Prob. Levy Tax } \\
\hline & 0.272 & 0.112 & 0.115 & 0.118 \\
\hline & $(0.111)$ & $(0.059)$ & $(0.052)$ & $(0.062)$ \\
\hline & {$[0.014]$} & {$[0.059]$} & {$[0.029]$} & {$[0.058]$} \\
\hline & & & Tax Rate & \\
\hline \multirow[t]{4}{*}{ Neighbors } & 0.396 & 0.165 & 0.167 & 0.168 \\
\hline & $(0.164)$ & $(0.084)$ & $(0.077)$ & $(0.091)$ \\
\hline & {$[0.016]$} & {$[0.051]$} & {$[0.030]$} & {$[0.063]$} \\
\hline & \multicolumn{4}{|c|}{ Panel C: Tax Revenue } \\
\hline \multirow[t]{3}{*}{ Neighbors } & 0.714 & 0.114 & 0.180 & 0.200 \\
\hline & $(0.345)$ & $(0.111)$ & $(0.101)$ & $(0.117)$ \\
\hline & {$[0.039]$} & {$[0.308]$} & {$[0.076]$} & {$[0.087]$} \\
\hline District $\mathrm{x}$ Year & Yes & Yes & Yes & Yes \\
\hline Controls & Yes & Yes & Yes & Yes \\
\hline Sample Period & $2005-2008$ & 2005-2009 & $2005-2010$ & $2005-2013$ \\
\hline Distance & $10 \mathrm{~km}$ & $20 \mathrm{~km}$ & $30 \mathrm{~km}$ & $30 \mathrm{~km}$ \\
\hline Observations & 468 & 585 & 702 & 1053 \\
\hline Municipalities & 117 & 117 & 117 & 117 \\
\hline
\end{tabular}

This table collects difference-in-differences regressions results from the estimation of Equation (1) using the fixed critical kilometer distance definition of neighborliness. The dependent variables are indicated above the coefficient estimates. All specifications include municipality fixed effects. Heteroscedasticity robust standard errors clustered at the municipal level in parentheses. P-values in brackets. 
Table 3: Yardstick Competition: Popular Vs. Unpopular Mayors Heterogeneous Effects

\begin{tabular}{|c|c|c|c|c|c|c|}
\hline & \multicolumn{2}{|c|}{ Pr. Levy Tax } & \multicolumn{2}{|c|}{ Tax Rate } & \multicolumn{2}{|c|}{ Tax Revenue } \\
\hline & I & II & III & IV & $\mathrm{V}$ & VI \\
\hline \multirow[t]{3}{*}{ Neighbors $\cdot$ Margin } & -0.154 & -0.109 & -0.226 & -0.152 & -0.312 & -0.186 \\
\hline & $(0.068)$ & $(0.051)$ & $(0.088)$ & $(0.069)$ & $(0.143)$ & $(0.118)$ \\
\hline & {$[0.024]$} & {$[0.032]$} & {$[0.010]$} & {$[0.028]$} & {$[0.029]$} & {$[0.114]$} \\
\hline \multirow[t]{3}{*}{ Neighbors } & 0.162 & 0.166 & 0.238 & 0.241 & 0.324 & 0.323 \\
\hline & $(0.062)$ & $(0.061)$ & $(0.090)$ & $(0.089)$ & $(0.141)$ & $(0.130)$ \\
\hline & {$[0.009]$} & {$[0.007]$} & {$[0.008]$} & {$[0.007]$} & {$[0.021]$} & {$[0.013]$} \\
\hline \multirow[t]{3}{*}{ Margin } & 0.073 & 0.027 & 0.113 & 0.037 & 0.227 & 0.117 \\
\hline & $(0.064)$ & $(0.047)$ & $(0.085)$ & $(0.064)$ & $(0.156)$ & $(0.102)$ \\
\hline & {$[0.255]$} & {$[0.570]$} & {$[0.184]$} & {$[0.568]$} & {$[0.145]$} & {$[0.251]$} \\
\hline District $\mathrm{x}$ year & Yes & Yes & Yes & Yes & Yes & Yes \\
\hline Controls & Yes & Yes & Yes & Yes & Yes & Yes \\
\hline Sample Period & 2005-13 & $2005-13$ & 2005-13 & $2005-13$ & 2005-13 & $2005-13$ \\
\hline Vote Margin & 5 & 10 & 5 & 10 & 5 & 10 \\
\hline Observations & 1053 & 1053 & 1053 & 1053 & 1053 & 1053 \\
\hline Municipalities & 117 & 117 & 117 & 117 & 117 & 117 \\
\hline
\end{tabular}

This table collects difference-in-differences regression results from the estimation of the heterogeneous effects model in Equation (3) using the contiguous definition of neighborliness and identifying mayors that won the previous election with a $5 \%$ or $10 \%$ victory margin. The dependent variables are indicated in the first row. All specifications include municipality fixed effects. Heteroscedasticity robust standard errors clustered at the municipal level in parentheses. P-values in brackets. 
Table 4: Yardstick Competition: Impact of Taxation on Electoral Outcomes

\begin{tabular}{|c|c|c|c|c|c|c|}
\hline & \multicolumn{2}{|c|}{ Pr. Levy Tax } & \multicolumn{2}{|c|}{ Tax Rate } & \multicolumn{2}{|c|}{ Tax Revenue } \\
\hline & I & II & III & IV & $\mathrm{V}$ & VI \\
\hline \multirow{4}{*}{$\operatorname{Tax}$} & \multicolumn{6}{|c|}{ Panel A: Probability of Reelection } \\
\hline & -0.025 & 0.137 & 0.004 & 0.106 & -0.011 & 0.073 \\
\hline & $(0.167)$ & $(0.092)$ & $(0.115)$ & $(0.066)$ & $(0.069)$ & $(0.041)$ \\
\hline & {$[0.879]$} & {$[0.136]$} & {$[0.975]$} & {$[0.108]$} & {$[0.876]$} & {$[0.075]$} \\
\hline \multirow{4}{*}{ Tax $\cdot$ Reelection } & \multicolumn{6}{|c|}{ Panel B: Incumbent Margin of Victory } \\
\hline & -0.001 & 0.020 & -0.006 & 0.014 & 0.016 & 0.009 \\
\hline & $(0.045)$ & $(0.018)$ & $(0.040)$ & $(0.013)$ & $(0.020)$ & $(0.009)$ \\
\hline & {$[0.987]$} & {$[0.249]$} & {$[0.873]$} & {$[0.271]$} & {$[0.426]$} & {$[0.322]$} \\
\hline \multirow[t]{3}{*}{ Reelection } & 0.025 & 0.012 & 0.025 & 0.011 & 0.023 & 0.012 \\
\hline & $(0.013)$ & $(0.011)$ & $(0.013)$ & $(0.011)$ & $(0.012)$ & $(0.011)$ \\
\hline & {$[0.051]$} & {$[0.283]$} & {$[0.050]$} & {$[0.287]$} & {$[0.058]$} & {$[0.270]$} \\
\hline \multirow[t]{3}{*}{ Tax } & 0.028 & -0.004 & 0.028 & -0.001 & 0.009 & -0.002 \\
\hline & $(0.031)$ & $(0.011)$ & $(0.031)$ & $(0.008)$ & $(0.013)$ & $(0.006)$ \\
\hline & {$[0.366]$} & {$[0.735]$} & {$[0.372]$} & {$[0.854]$} & {$[0.476]$} & {$[0.743]$} \\
\hline District $\mathrm{x}$ Year & Yes & Yes & Yes & Yes & Yes & Yes \\
\hline Controls & Yes & Yes & Yes & Yes & Yes & Yes \\
\hline Sample Period & 2005-09 & 2005-13 & 2005-09 & 2005-13 & 2005-09 & $2005-13$ \\
\hline Observations & 234 & 351 & 234 & 351 & 234 & 351 \\
\hline Municipalities & 117 & 117 & 117 & 117 & 117 & 117 \\
\hline
\end{tabular}

This table collects regressions results from the estimation of fixed effects models regressing the outcome variables (Panel A) probability of reelection and (Panel B) the incumbent's victory margin on each of the tax variables in the first row. Panel B studies the impact of the tax variables conditional on reelection. All specifications include municipality fixed effects. Heteroscedasticity robust standard errors clustered at the municipal level in parentheses. P-values in brackets. 
Table 5: Negative Spillover Effects

\begin{tabular}{|c|c|c|c|c|c|}
\hline \multicolumn{2}{|c|}{ Pr. Levy Tax } & \multicolumn{2}{|c|}{ Tax Rate } & \multicolumn{2}{|c|}{ Tax Revenue } \\
\hline I & II & III & IV & $\mathrm{V}$ & VI \\
\hline
\end{tabular}

Panel A: Exclude 100\% surrounded municipalities

$\begin{array}{lllllll}\text { Neighbors } & 0.144 & 0.147 & 0.208 & 0.214 & 0.286 & 0.291 \\ & (0.057) & (0.062) & (0.082) & (0.090) & (0.129) & (0.140) \\ & {[0.011]} & {[0.018]} & {[0.011]} & {[0.017]} & {[0.027]} & {[0.038]} \\ \text { Observations } & 654 & 981 & 654 & 981 & 654 & 981 \\ \text { Municipalities } & 109 & 109 & 109 & 109 & 109 & 109\end{array}$

Panel B: Exclude 50\% surrounded municipalities

\begin{tabular}{|c|c|c|c|c|c|c|}
\hline \multirow[t]{3}{*}{ Neighbors } & 0.127 & 0.138 & 0.184 & 0.204 & 0.192 & 0.212 \\
\hline & $(0.058)$ & $(0.065)$ & $(0.085)$ & $(0.095)$ & $(0.106)$ & $(0.124)$ \\
\hline & {$[0.028]$} & {$[0.034]$} & {$[0.030]$} & {$[0.031]$} & {$[0.070]$} & {$[0.088]$} \\
\hline Observations & 420 & 630 & 420 & 630 & 420 & 630 \\
\hline Municipalities & 70 & 70 & 70 & 70 & 70 & 70 \\
\hline District $\mathrm{x}$ Year & Yes & Yes & Yes & Yes & Yes & Yes \\
\hline Controls & Yes & Yes & Yes & Yes & Yes & Yes \\
\hline Sample Period & 2005-10 & 2005-13 & 2005-10 & $2005-13$ & 2005-10 & $2005-13$ \\
\hline
\end{tabular}

This table collects difference-in-differences regressions results from reestimating Equation (1) using the contiguous definition of neighborliness and samples that exclude municipalities that are (Panel A) 100\% or (Panel B) over 50\% surrounded by excluded municipalities. The dependent variables are indicated in the first row. All specifications include municipality fixed effects. Heteroscedasticity robust standard errors clustered at the municipal level in parentheses. P-values in brackets. 
Table 6: Social Learning

\begin{tabular}{|c|c|c|c|c|c|c|}
\hline & \multicolumn{2}{|c|}{ Pr. Levy Tax } & \multicolumn{2}{|c|}{ Tax Rate } & \multicolumn{2}{|c|}{ Tax Revenue } \\
\hline & I & II & III & IV & $\mathrm{V}$ & VI \\
\hline \multirow[t]{3}{*}{ Neighbors } & 0.118 & 0.120 & 0.175 & 0.175 & 0.250 & 0.253 \\
\hline & $(0.050)$ & $(0.054)$ & $(0.073)$ & $(0.079)$ & $(0.127)$ & $(0.134)$ \\
\hline & {$[0.018]$} & {$[0.026]$} & {$[0.017]$} & {$[0.027]$} & {$[0.049]$} & {$[0.060]$} \\
\hline \multirow[t]{3}{*}{2009} & -0.070 & -0.111 & -0.094 & -0.157 & -0.058 & -0.063 \\
\hline & $(0.054)$ & $(0.059)$ & $(0.077)$ & $(0.084)$ & $(0.109)$ & $(0.125)$ \\
\hline & {$[0.193]$} & {$[0.060]$} & {$[0.222]$} & {$[0.062]$} & {$[0.596]$} & {$[0.613]$} \\
\hline \multirow[t]{3}{*}{2010} & -0.116 & 0.217 & -0.123 & 0.285 & -0.240 & 0.066 \\
\hline & $(0.066)$ & $(0.121)$ & $(0.083)$ & $(0.132)$ & $(0.117)$ & $(0.172)$ \\
\hline & {$[0.080]$} & {$[0.072]$} & {$[0.139]$} & {$[0.031]$} & {$[0.040]$} & {$[0.700]$} \\
\hline \multirow[t]{3}{*}{2011} & & -0.087 & & -0.131 & & -0.168 \\
\hline & & $(0.096)$ & & $(0.142)$ & & $(0.278)$ \\
\hline & & {$[0.367]$} & & {$[0.354]$} & & {$[0.545]$} \\
\hline \multirow[t]{3}{*}{2012} & & 0.006 & & 0.013 & & 0.072 \\
\hline & & $(0.188)$ & & $(0.281)$ & & $(0.490)$ \\
\hline & & {$[0.974]$} & & {$[0.964]$} & & {$[0.883]$} \\
\hline \multirow[t]{3}{*}{2013} & & -0.099 & & -0.148 & & -0.055 \\
\hline & & $(0.171)$ & & $(0.257)$ & & $(0.431)$ \\
\hline & & {$[0.563]$} & & {$[0.565]$} & & {$[0.899]$} \\
\hline District $\mathrm{x}$ Year & Yes & Yes & Yes & Yes & Yes & Yes \\
\hline Controls & Yes & Yes & Yes & Yes & Yes & Yes \\
\hline Sample Period & 2005-10 & 2005-13 & 2005-10 & 2005-13 & $2005-10$ & $2005-13$ \\
\hline Observations & 702 & 1053 & 702 & 1053 & 702 & 1053 \\
\hline Municipalities & 117 & 117 & 117 & 117 & 117 & 117 \\
\hline
\end{tabular}

This table collects difference-in-differences regressions from the estimation of Equation (4) using the contiguous definition of neighborliness. The dependent variables are indicated in the first row. All specifications include municipality fixed effects. Heteroscedasticity robust standard errors clustered at the municipal level in parentheses. P-values in brackets. 
Table A.1: Means Comparison

\begin{tabular}{|c|c|c|c|c|c|c|}
\hline & & Treatment & Control & Difference & & \\
\hline \multirow[t]{2}{*}{ Income Tax Rev. } & Mean & 2.660 & 2.693 & -0.034 & t-Statistic & -0.354 \\
\hline & Std. error & 0.046 & 0.075 & 0.095 & p-Value & 0.724 \\
\hline \multirow[t]{2}{*}{ Property Tax Rev. } & Mean & 1.164 & 0.999 & 0.165 & t-Statistic & 0.422 \\
\hline & Std. error & 0.190 & 0.316 & 0.392 & p-Value & 0.674 \\
\hline \multirow[t]{2}{*}{ Municipal Taxes } & Mean & 3.989 & 3.779 & 0.210 & $\mathrm{t}$-Statistic & 1.470 \\
\hline & Std. error & 0.065 & 0.143 & 0.143 & p-Value & 0.144 \\
\hline \multirow[t]{2}{*}{ Total Tax Rev. } & Mean & 4.738 & 4.551 & 0.187 & t-Statistic & 1.157 \\
\hline & Std. error & 0.075 & 0.153 & 0.161 & p-Value & 0.250 \\
\hline \multirow[t]{2}{*}{ Municipal Fees } & Mean & 2.594 & 2.621 & -0.027 & t-Statistic & -0.179 \\
\hline & Std. error & 0.069 & 0.142 & 0.149 & p-Value & 0.858 \\
\hline \multirow[t]{2}{*}{ General Transfer } & Mean & 5.586 & 5.799 & -0.213 & t-Statistic & -1.127 \\
\hline & Std. error & 0.092 & 0.145 & 0.189 & p-Value & 0.262 \\
\hline \multirow[t]{2}{*}{ Specific Transfer } & Mean & 2.778 & 2.782 & -0.004 & t-Statistic & -0.048 \\
\hline & Std. error & 0.046 & 0.050 & 0.090 & p-Value & 0.962 \\
\hline \multirow[t]{2}{*}{ Total Current Rev. } & Mean & 6.584 & 6.694 & -0.110 & t-Statistic & -1.332 \\
\hline & Std. error & 0.040 & 0.064 & 0.082 & p-Value & 0.185 \\
\hline \multirow[t]{2}{*}{ No. Companies } & Mean & 1605.613 & 1248.333 & 357.280 & t-Statistic & 0.924 \\
\hline & Std. error & 193.611 & 263.728 & 386.869 & p-Value & 0.358 \\
\hline \multirow[t]{2}{*}{ Sales Volume } & Mean & 240783.3 & 153075.8 & 87707.98 & t-Statistic & 1.239 \\
\hline & Std. error & 35863.39 & 44150.19 & 70788.52 & p-Value & 0.218 \\
\hline \multirow[t]{2}{*}{ Unemployment } & Mean & 551.946 & 432.222 & 119.724 & t-Statistic & 0.951 \\
\hline & Std. error & 63.676 & 79.932 & 125.961 & p-Value & 0.344 \\
\hline \multirow[t]{2}{*}{ Income } & Mean & 3763.151 & 3865.538 & -102.388 & t-Statistic & -0.166 \\
\hline & Std. error & 303.208 & 435.541 & 618.656 & p-Value & 0.869 \\
\hline \multirow[t]{2}{*}{ Population } & Mean & 15798.51 & 11881.3 & 3917.209 & t-Statistic & 1.300 \\
\hline & Std. error & 1540.365 & 1734.384 & 3012.822 & p-Value & 0.196 \\
\hline \multirow[t]{2}{*}{ Left Council } & Mean & 0.341 & 0.370 & -0.030 & t-Statistic & -0.282 \\
\hline & Std. error & 0.050 & 0.095 & 0.105 & p-Value & 0.778 \\
\hline \multirow[t]{2}{*}{ Vote margin } & Mean & 0.219 & 0.188 & 0.030 & t-Statistic & 0.901 \\
\hline & Std. error & 0.017 & 0.025 & 0.034 & p-Value & 0.370 \\
\hline \multirow[t]{2}{*}{ Council vote share } & Mean & 0.561 & 0.571 & -0.010 & t-Statistic & -0.472 \\
\hline & Std. error & 0.010 & 0.014 & 0.020 & p-Value & 0.638 \\
\hline \multirow[t]{2}{*}{ Assembly vote share } & Mean & 0.564 & 0.583 & -0.019 & t-Statistic & -1.019 \\
\hline & Std. error & 0.010 & 0.013 & 0.019 & p-Value & 0.311 \\
\hline
\end{tabular}

This table collects a means comparison between treatment and control municipalities for a number of socio-economic and political observable characteristics. 
Table A.2: Balance Tests

\begin{tabular}{llll}
\hline & Coefficient & Std. error & P-value \\
\hline Income Tax Rev. & -.038313 & .1045735 & 0.715 \\
Property Tax Rev. & .1636475 & .1447154 & 0.260 \\
Municipal Taxes & -.038313 & .1045735 & 0.715 \\
Total Tax Rev. & .1570757 & .1433318 & 0.275 \\
Municipal Fees & .0611588 & .1466561 & 0.677 \\
General Transfer & -.2213259 & .1722291 & 0.201 \\
Specific Transfer & -.0096699 & .0687058 & 0.888 \\
Total Current Rev. & -.1115116 & .0752514 & 0.141 \\
No. Companies & 378.8222 & 328.8378 & 0.252 \\
Sales Volume & 89569.24 & 57260.02 & 0.120 \\
Unemployment & 126.7778 & 102.7999 & 0.220 \\
Income & -49.64957 & 532.2059 & 0.926 \\
Population & 4114.559 & 2337.539 & 0.081 \\
Left Council & -.0259259 & .1064878 & 0.808 \\
Vote margin & .0280969 & .0298757 & 0.349 \\
Council vote share & -.0098216 & .0168391 & 0.561 \\
Assembly vote share & -.0191169 & .0160857 & 0.237 \\
\hline
\end{tabular}

This table collects balance tests between treatment and control municipalities for a number of socio-economic and political observable characteristics. 
Table A.3: Tax Mimicking: Within Economic Region Neighbors

\begin{tabular}{|c|c|c|c|c|c|c|}
\hline & \multicolumn{2}{|c|}{ Pr. Levy Tax } & \multicolumn{2}{|c|}{ Tax Rate } & \multicolumn{2}{|c|}{ Tax Revenue } \\
\hline & I & II & III & IV & $\mathrm{V}$ & VI \\
\hline \multirow[t]{3}{*}{ Region } & 0.136 & 0.127 & 0.197 & 0.185 & 0.266 & 0.247 \\
\hline & $(0.054)$ & $(0.061)$ & $(0.079)$ & $(0.088)$ & $(0.125)$ & $(0.136)$ \\
\hline & {$[0.012]$} & {$[0.037]$} & {$[0.013]$} & {$[0.035]$} & {$[0.033]$} & {$[0.071]$} \\
\hline \multirow[t]{3}{*}{$\neq$ Region } & 0.123 & 0.189 & 0.184 & 0.286 & 0.300 & 0.440 \\
\hline & $(0.061)$ & $(0.099)$ & $(0.088)$ & $(0.146)$ & $(0.141)$ & $(0.248)$ \\
\hline & {$[0.043]$} & {$[0.055]$} & {$[0.038]$} & {$[0.050]$} & {$[0.033]$} & {$[0.076]$} \\
\hline District $\mathrm{x}$ Year & Yes & Yes & Yes & Yes & Yes & Yes \\
\hline Controls & Yes & Yes & Yes & Yes & Yes & Yes \\
\hline Sample Period & 2005-10 & 2005-13 & 2005-10 & 2005-13 & 2005-10 & $2005-13$ \\
\hline Observations & 702 & 1053 & 702 & 1053 & 702 & 1053 \\
\hline Municipalities & 117 & 117 & 117 & 117 & 117 & 117 \\
\hline
\end{tabular}

This table collects difference-in-differences regression results from the estimation of Equation (1) using the within economic region definition of neighborliness. The dependent variables are indicated in the first row. All specifications include municipality fixed effects. Heteroscedasticity robust standard errors clustered at the municipal level in parentheses. P-values in brackets. 
Table A.4: Tax and Expenditure Competition

\begin{tabular}{|c|c|c|c|c|c|c|}
\hline & \multicolumn{2}{|c|}{ Expenditure } & \multicolumn{2}{|c|}{ B. Volume } & \multicolumn{2}{|c|}{ No. companies } \\
\hline & I & II & III & IV & $\mathrm{V}$ & VI \\
\hline \multirow[t]{3}{*}{ Levy Tax } & -0.016 & 0.009 & 0.023 & 0.009 & 0.004 & 0.004 \\
\hline & $(0.053)$ & $(0.025)$ & $(0.049)$ & $(0.045)$ & $(0.009)$ & $(0.008)$ \\
\hline & {$[0.766]$} & {$[0.730]$} & {$[0.642]$} & {$[0.842]$} & {$[0.656]$} & {$[0.593]$} \\
\hline \multirow[t]{3}{*}{ Tax Rate } & 0.001 & 0.007 & 0.014 & 0.003 & 0.006 & 0.005 \\
\hline & $(0.043)$ & $(0.018)$ & $(0.037)$ & $(0.035)$ & $(0.007)$ & $(0.005)$ \\
\hline & {$[0.986]$} & {$[0.709]$} & {$[0.710]$} & {$[0.937]$} & {$[0.377]$} & {$[0.331]$} \\
\hline \multirow[t]{3}{*}{ Tax Revenue } & -0.001 & 0.002 & 0.028 & 0.020 & -0.001 & 0.001 \\
\hline & $(0.021)$ & $(0.011)$ & $(0.028)$ & $(0.022)$ & $(0.004)$ & $(0.003)$ \\
\hline & {$[0.980]$} & {$[0.853]$} & {$[0.325]$} & {$[0.349]$} & {$[0.806]$} & {$[0.856]$} \\
\hline District $\mathrm{x}$ Year & Yes & Yes & Yes & Yes & Yes & Yes \\
\hline Controls & Yes & Yes & Yes & Yes & Yes & Yes \\
\hline Sample Period & $2005-10$ & 2005-13 & $2005-10$ & $2005-13$ & 2005-10 & $2005-13$ \\
\hline Observations & 702 & 1053 & 702 & 936 & 701 & 935 \\
\hline Municipalities & 117 & 117 & 117 & 117 & 117 & 117 \\
\hline
\end{tabular}

This table collects regressions results from fixed effects models regressing the outcome variables in the first row - the log of per capita municipal current expenditures, municipal business volume, and the number of firms located in a municipality - on each of the tax variables under study on the first column. All specifications include municipality fixed effects. Heteroscedasticity robust standard errors clustered at the municipal level in parentheses. P-values in brackets. 
Table A.5: Yearly regressions

\begin{tabular}{|c|c|c|c|}
\hline & Pr. Levy Tax & Tax Rate & Tax Revenue \\
\hline \multirow[t]{3}{*}{2008} & 0.112 & 0.171 & 0.217 \\
\hline & $(0.054)$ & $(0.082)$ & $(0.135)$ \\
\hline & {$[0.041]$} & {$[0.036]$} & {$[0.108]$} \\
\hline \multirow[t]{3}{*}{2009} & 0.141 & 0.206 & 0.291 \\
\hline & $(0.057)$ & $(0.083)$ & $(0.134)$ \\
\hline & {$[0.013]$} & {$[0.013]$} & {$[0.029]$} \\
\hline \multirow[t]{3}{*}{2010} & 0.156 & 0.218 & 0.303 \\
\hline & $(0.057)$ & $(0.079)$ & $(0.121)$ \\
\hline & {$[0.006]$} & {$[0.006]$} & {$[0.013]$} \\
\hline \multirow[t]{3}{*}{2011} & 0.230 & 0.314 & 0.396 \\
\hline & $(0.066)$ & $(0.091)$ & $(0.169)$ \\
\hline & {$[0.000]$} & {$[0.001]$} & {$[0.019]$} \\
\hline \multirow[t]{3}{*}{2012} & 0.096 & 0.152 & 0.228 \\
\hline & $(0.107)$ & $(0.153)$ & $(0.225)$ \\
\hline & {$[0.370]$} & {$[0.319]$} & {$[0.311]$} \\
\hline \multirow[t]{3}{*}{2013} & 0.058 & 0.102 & 0.141 \\
\hline & $(0.106)$ & $(0.154)$ & $(0.219)$ \\
\hline & {$[0.586]$} & {$[0.507]$} & {$[0.520]$} \\
\hline District $\mathrm{x}$ Year & Yes & Yes & Yes \\
\hline Controls & Yes & Yes & Yes \\
\hline Observations & 1053 & 1053 & 1053 \\
\hline Municipalities & 117 & 117 & 117 \\
\hline
\end{tabular}

This table collects difference-in-differences yearly regressions results from the estimation of Equation (2) using the contiguous definition of neighborliness. The dependent variables are indicated in the first row. All specifications include municipality fixed effects. Heteroscedasticity robust standard errors clustered at the municipal level in parentheses. P-values in brackets. 